\title{
大阪市とその周辺における低温濃縮法による 環境臭気濃度の測定とその原因物質
}

\author{
増田 淳二, 板野 泰之, 福山 丈二
}

\begin{abstract}
都市大気は，はっきりとにおわないまで屯污染による何らかの臭気を持つ。低温濃縮-嗅覚測定法を用い て大阪市およびその周辺地域において臭気濃度を測定し, あわせて種々の物質濃度測定を行い, 臭気濃度と の関係について論じた。

26 箇所の地点で合計 92 件測定した臭気濃度は最小 0.3 から最大 5.6 の範囲にあり, 各地点毎の幾何平均 では 0.6 から 3.6 の範囲にあった。一般に沿道で臭気濃度が高く, 郊外や河川敷で低い傾向にあった. 測定し た臭気物質の中ではアセトアルデヒドが最も一般環境の臭気濃度への寄与が大きいと考えられた.
\end{abstract}

\section{1. 緒言}

工場や下水処理場等の周辺においては悪臭が感じられ ることがあり，においが強い場合には規制の対象とな る。規制の対象となるレベルでは，三点比較式臭袋法に よる臭気濃度の測定が可能である。しかしながら，都市 生活の快適性という観点からはより低濃度のたとえば道 路沿いにおいて何となく感じるか感じないかのレベルの においも測定することが重要である，あるいは，仮に閾 值以下であっても何らかの臭気ポテンシャルレベルの差 ああるであろう。

三点比較式臭袋法での測定下限は，一般に臭気濃度 10 となっている，臭気濃度 10 以下を測定するためには, 濃 縮操作を行ったのち臭気濃度を測定する必要が生ずる. 日本では，これまで Tenax-TA, Unicarbon B および Carbosieve SIII どを充填した濃縮管を用いて常温で 臭気を捕集し, 窒素気流中で加熱脱着後, 測定する方法 が広く行われている ${ }^{1) \sim 8)}$. しかしながら, 本方法では, 硫 化水素やアンモニアなど代表的な悪臭成分が捕捉できな

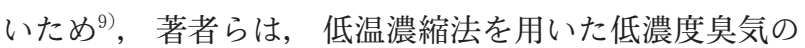
測定を検討し報告した ${ }^{10)}$.

本報では，この低温濃縮法を用いて大阪市およびその 周辺地域において低濃度臭気の臭気濃度測定を行い，あ わせて幾つかの物質濃度を測定し, 主原因物質について 検討した結果について報告する。

\section{2. 方法}

\section{1 調査地点, 調査日および測定項目}

調査は, 大阪市内の地点で 2002 年秋から予備的に開
始し， 2003 年 4 月から 2004 年 3 月にかけては，毎月 1 回の頻度で市内 4 地点を選定し試料採取を行った。な お，大阪市内における臭気レベルを検討するには比較的 清浄な地域と対比する必要があると考え, 2004 年 4 月か ら 2005 年 3 月にかけては，前年と同様に毎月 1 回の頻 度で大阪市内とその周辺地域について試料の採取を行っ た. 測定地点について, 図ー1に, また各地点の特徵およ び試料採取期間について表一 1 に示す.

試料の採取は，携帯ポンプ（近江オドエアーサービス （株）製 DC-1C）を用いてポリエステル製採取バッグ（近 江オドェアーサービス(株) 製フレックサンプラー 100 F）に5〜7 分程度かけて 150L 以上の空気を採取した。 測定地点間は車で移動し, 1 日の試料採取数は 4 件（地 点）である. 試料採取後, 実験室に持ち帰り直ちに次項 に示す方法で濃縮操作を行い，臭気濃度測定を行った。

2003 年 6 月以降の試料採取時には, バッグ採取に合わ せて米国環境保護局有害大気污染物質測定法 $(\mathrm{TO}-14)^{11)}$ に準じて，6L キャニスター（ジーエルサイエンス(株) 製 S-Can キャニスター) を用いて空気試料を採取し，自 動濃縮装置（Entech Instruments, Inc. 製 7100A) -ガス クロマトグラフ質量分析計 (Agilent Technologies 製 6890 Series/5973N inert）を用いて大気中成分を測定し た。分析用標準ガスとしては, 住友精化(株) 製標準ガス JHAPs-J 44 および高千穂化学工業 (株) 製標準ガス PAMS58 を用いた。 したがってこれらに含まれる成分 で，かつ臭気物質として嗅覚閾值が永田ら ${ }^{12)} に よ り$ 報告 されているものを分析対象とした。具体的には，プロペ ン, 1 -ブテン, $n$-ブタン, イソブタン, イソペンタン,

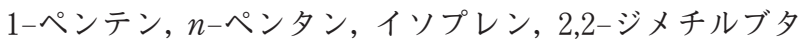

増田 淳二（ますだ じゅんじ）, 板野 泰之（いたの やすゆき）, 福山 丈二（ふくやま じょうじ）

大阪市立環境科学研究所 =543-0026 大阪市天王寺区東上町 8-34 TEL 06-6771-3043，FAX 06-6772-0676 
ン, 2,3-ジメチルブタン, 2-メチルペンタン, 3-メチルペ

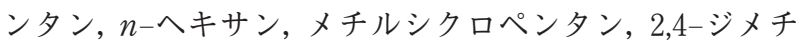
ルペンタン, ベンゼン, シクロヘキサン, 2 -メチルヘキ サン，2,3-ジメチルペンタン，3-メチルヘキサン，2,2,4トリメチルペンタン, ヘプタン, メチルシクロヘキサン, トルエン，2-メチルヘプタン，3-メチルヘプタン，オク タン, エチルベンゼン, $m$-キシレン, $p$-キシレン, スチ レン, $O$-キシレン, ノナン, イソプロピルベンゼン, $\alpha-$ ピネン, プロピルベンゼン, $p$-エチルトルエン, $m$-エチ ルトルエン, 1,3,5-トリメチルベンゼン, $O$-エチルトルエ ン, $\beta$-ピネン, 1,2,4-トリメチルベンゼン, $m$-ジエチル ベンゼン, $p$-ジェチルベンゼン, 1,3-ブタジエン, アクリ ロニトリル, ジクロロメタン, クロロホルム, 四塩化炭 素, トリクロロエチレンおよびテトラクロロエチレンで ある。

また, 2004 年 4 月以降は, 臭気濃度測定用低温濃縮 後, 採取バッグ内に残った空気試料を悪臭防止法に定め る方法に準拠して 2,4-DNPH カートリッジに捕集・溶 出し, FTD 付ガスクロマトグラフ ((株)島津製作所製ガ スクロマトグラフ GC-14B）で低級脂肪族アルデヒド類 の濃度を測定した. 2004 年 5 月以降の試料については, 嗅覚測定用に濃縮した試料の $100 \mathrm{~mL}$ をさらに，悪臭防 止法に定める方法に準拠して低温濃縮し，FPD 付ガス クロマトグラフ ((株)島津製作所製ガスクロマトグラフ GC-14B）で硫黄系成分（硫化水素, メチルメルカプタ
ン，硫化メチル，二硫化メチル，硫化カルボニルおよび 二硫化メチル）の濃度を測定した。

また， 2004 年 5 月以降は，図－1 に示す A 地点のみ悪 臭防止法に定める方法に準拠してアルカリビーズを用い て捕集し，FID 付ガスクロマトグラフ（(株)日立製作所 製ガスクロマトグラフ GC263-30 型）により低級脂肪酸 類（酢酸，プロピオン酸，ノルマル酪酸，イソ酪酸，ノ ルマル吉草酸，イソ吉草酸）の測定を行った. ただし， 低級脂肪酸については, 検出限界を下げるために $1 \mathrm{~m}^{3}$ 程 度の試料を採取する必要があり，吸引時間として数時間 を要したために臭気濃度測定用試料の試料採取時間（5 ～7 分程度）とは一致していない。

\section{2 低温濃縮法による臭気濃度の測定}

臭気濃度の測定は，既報 ${ }^{10)}$ に示すとおりである。すな わち, 試料の捕集は U 字管 (ガラス製, 内径 $13 \mathrm{~mm}$ ) に Tenax-TA ${ }^{\circledR}(60 / 80$ メッシュ) を $4 \mathrm{~g}$ 充填し (以下, Tenax-U 字管), 液体酸素に浸けることにより冷却して試 料空気を毎分 $1 \mathrm{~L}$ 程度の流量で導入した. 空気中の水分 の凝縮によって Tenax-U 字管が閉塞することを防ぐた めに，図ー2 に示すように前段に空の U 字管を 2 連に接 続した. 試料の脱着は, 図ー3に示すように, 窒素を毎分 20 30 mL で流しながら恒温槽内で $180^{\circ} \mathrm{C}$ まで加熱して 吸着成分を追い出し，ポリエステル製の試料採取バッグ （近江オドェアー(株）製フレックサンプラー 1F） に50

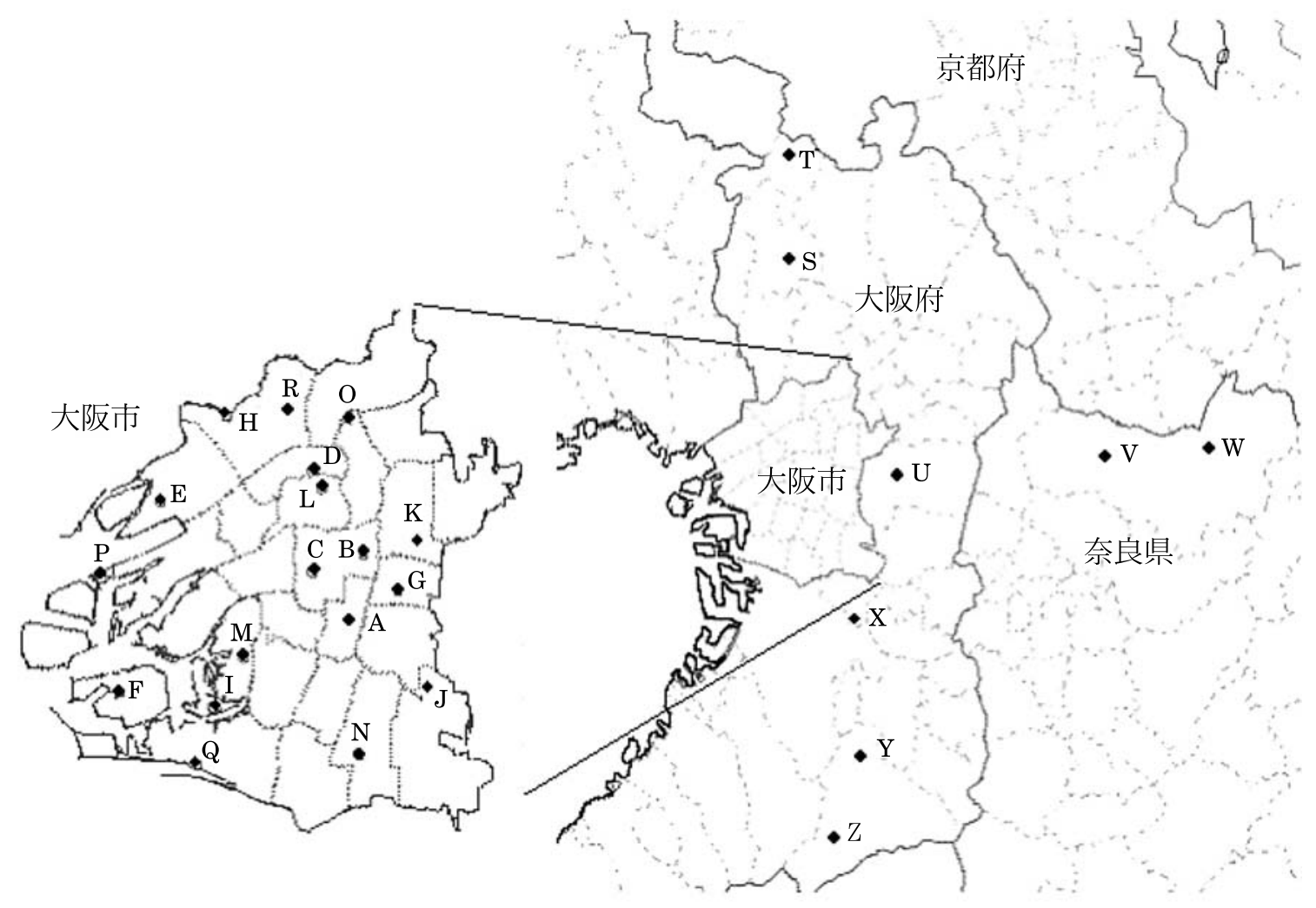

図 -1 試料採取地点 


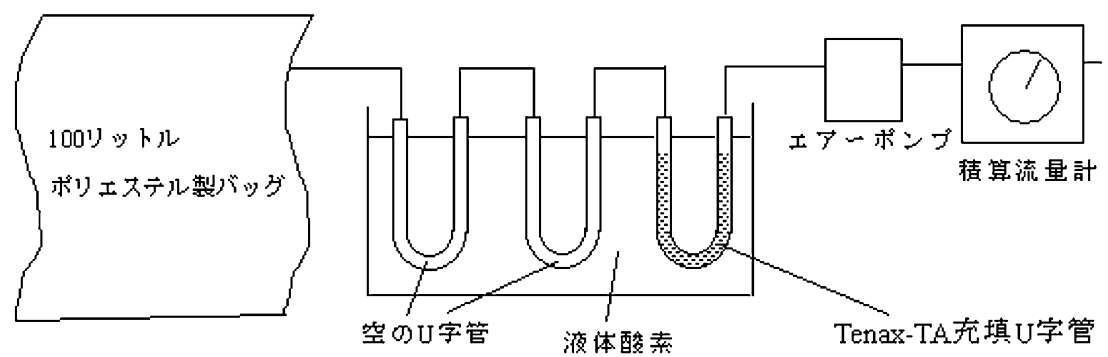

図-2 臭気の濃縮操作図

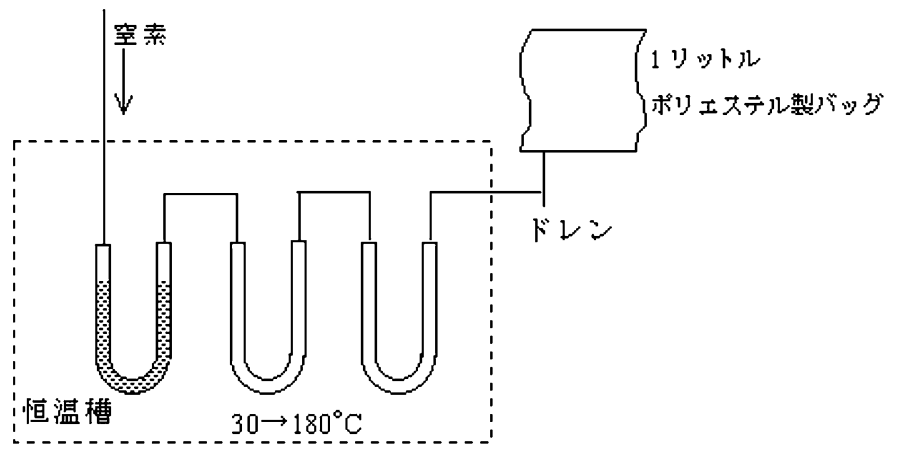

図-3 臭気の脱着回収操作図

分程度かけて回収した. なお,この濃縮操作では $100 \mathrm{~L}$ 程度の空気の捕集を行ったが，その際には数 $\mathrm{mL}$ 程度の 水分が捕集され, 脱着時に水滴が生成するため, 図一3 に示すように T 字管を接続して重力的に分離した.

濃縮した試料は，嗅覚測定法（三点比較式臭袋法）に より臭気濃度を測定し, 次式により環境中臭気濃度を得 た。ここで，捕集空気量は積算流量計で計測し，脱着試 料量は嗅覚測定等に用いた試料量と, 残った試料量を注 射筒で量った体積の合計量とした。

環境臭気濃度 $=$ 濃縮試料の臭気濃度 $\times$ 脱着試料量 $(\mathrm{L})$ $\div$ 捕集空気量 $(\mathrm{L})$

\section{3. 結果および考察}

\section{1 臭気濃度の測定結果}

臭気濃度の測定結果の概要を表一 1 に示す。表一1 に は，各地点における臭気濃度の測定結果をもとに複数回 測定した場合には幾何平均值を示し, 併せて最大值と最 小值も示した，各地点においては当然ながら測定值はば らつき，最大值は A 地点の 5.6 であるが，これは，試料 採取当日に近隣での建築工事に伴ってアスファルト臭が 感じられていたためである。

各地点で測定した臭気濃度のうち, 平均值が最も高い 值は $\mathrm{U}$ 地点の 3.8 で, 次いで $\mathrm{H}$ 地点の 2.8 であった. $\mathrm{U}$ 地点は東西南北方向に幹線道路が走っており，それに重
なるように高架高速道路がある非常に交通量の大きい地 点であり, 3 回の測定結果はいずれも大きく, 最小でも 3.1 であった. このほか, B 地点, C 地点, D 地点, E 地 点, $\mathrm{G}$ 地点および $\mathrm{R}$ 地点なども交通量の多い地点であ る。辰市ら ${ }^{2), 3)}$ の常温吸着濃縮による測定では，道路直 近では臭気濃度が 10 を超える場合も観測されており， 今回の結果はそれらと比較するとやや低い值であった。 一方, $\mathrm{H}$ 地点は近隣工場からの臭気が若干感じられる状 況にあった. 川沿い（O〜Q 地点）は平均で 1 以下と低 く, W 地点や $Z$ 地点などの郊外では同様に低い值が観 察された。

\section{2 測定した臭気物質との相関性}

測定した臭気物質のうち代表的なものとして，ベンゼ ン，トルエン（2003 年 4 月から 2005 年 3 月までのデー 夕), 硫化水素, アセトアルデヒド濃度 (2004 年 4 月から 2005 年 3 月までのデータ) と臭気濃度の測定結果との関 係を図-4 に示す.

これらの図を見る限り，物質濃度が明確に臭気濃度と の関連性を持っているとは言いきれない。 また，これら の物質の嗅覚閾値について, 永田らが三点比較式臭袋法 で求めた值 ${ }^{12)}$ は, ベンゼン $2.7 \mathrm{ppm}$, トルエン $0.33 \mathrm{ppm}$, 硫化水素 $0.00041 \mathrm{ppm}$ およびアセトアルデヒド 0.0015 ppm であり，図-4に示す物質濃度の測定結果と比べた 場合にベンゼンで閾值の $1 / 1000$ 程度以下，トルエンで 
表 -1 各試料採取地点の特徵および臭気濃度測定結果の概要

\begin{tabular}{|c|c|c|c|c|c|c|}
\hline \multirow{2}{*}{$\begin{array}{c}\text { 試料採取 } \\
\text { 地点 }\end{array}$} & \multirow{2}{*}{$\begin{array}{c}\text { 位置 } \\
\text { (特徵) }\end{array}$} & \multirow{2}{*}{ 調査期間 } & \multirow{2}{*}{ 測定回数 } & \multicolumn{3}{|c|}{ 臭気濃度測定結果 } \\
\hline & & & & 幾何平均 & 最大值 & 最小值 \\
\hline A & 大阪市内 (市立環境科学研究所前) & 2004年4月 - 2005年3月 & 12 & 1.7 & 5.6 & 0.6 \\
\hline $\mathrm{B}$ & " （沿道 $)$ & 2002年9月 - 2004年1月 & 4 & 1.4 & 2.6 & 0.8 \\
\hline $\mathrm{C}$ & " （沿道） & 2003年2月 - 2005年1月 & 6 & 1.5 & 2.1 & 0.9 \\
\hline $\mathrm{D}$ & " （沿道） & 2003年11月 & 1 & 2.0 & - & - \\
\hline $\mathrm{E}$ & " （沿道） & 2002年9月 - 2004年2月 & 3 & 1.6 & 1.9 & 1.0 \\
\hline $\mathrm{F}$ & " （沿道） & 2003年2月, 2004年3月 & 2 & 0.9 & 1.0 & 0.7 \\
\hline G & "I沿道） & 2003年8月, 2004年2月 & 2 & 1.1 & 1.6 & 0.8 \\
\hline $\mathrm{H}$ & " （工業地域） & 2002年9月 - 2004年 2 月 & 4 & 2.8 & 3.6 & 2.0 \\
\hline I & " (工業地域、沿道) & 2003年2月 - 2005年1月 & 6 & 0.9 & 1.3 & 0.5 \\
\hline $\mathrm{J}$ & " （下水処理場周辺） & 2002年10月 - 2005年1月 & 5 & 0.9 & 1.7 & 0.6 \\
\hline $\mathrm{K}$ & $"$ （下水処理場周辺） & 2002年10月-2004年1月 & 3 & 0.6 & 0.8 & 0.5 \\
\hline $\mathrm{L}$ & " (公園) & 2003 年 5 月, 2003 年 11 月 & 2 & 1.2 & 2.2 & 0.6 \\
\hline M & " (公園) & 2003年7月, 2004年3月 & 2 & 1.2 & 2.0 & 0.7 \\
\hline $\mathrm{N}$ & " （公園） & 2003年8月 - 2004年3月 & 3 & 0.8 & 1.0 & 0.6 \\
\hline $\mathrm{O}$ & " （河川敷） & 2002年9月 - 2003年9月 & 4 & 0.6 & 1.1 & 0.3 \\
\hline $\mathrm{P}$ & "I河岸） & 2003年6月- 2004年2月 & 3 & 0.8 & 1.2 & 0.6 \\
\hline $\mathrm{Q}$ & "I (河岸) & 2003 年 2 月 -2003 年 12 月 & 3 & 0.6 & 1.2 & 0.3 \\
\hline $\mathrm{R}$ & " $\quad$ （浻道） & 2004年7月- 2005年3月 & 3 & 1.9 & 3.6 & 1.2 \\
\hline $\mathrm{S}$ & 箕面市 （沿道） & 2004年7月 - 2005 年3月 & 3 & 1.2 & 1.7 & 0.6 \\
\hline $\mathrm{T}$ & 豊能町 （沿道、川沿） & 2004 年7月 - 2005 年3月 & 3 & 1.0 & 1.6 & 0.7 \\
\hline $\mathrm{U}$ & 東大阪市 (沿道) & 2004年6月 - 2005年2月 & 3 & 3.8 & 5.1 & 3.1 \\
\hline $\mathrm{V}$ & 奈良市 （公園前） & 2004年6月 - 2005年2月 & 3 & 1.2 & 1.5 & 0.9 \\
\hline W & 奈良市（山間、沿道） & 2004年6月 - 2005年2月 & 3 & 0.6 & 1.3 & 0.4 \\
\hline $\mathrm{X}$ & 松原市 （沿道） & 2004年4月- 2004年12月 & 3 & 1.9 & 1.9 & 1.8 \\
\hline $\mathrm{Y}$ & 河内長野市 (沿道) & 2004 年 4 月 - 2004年 12 月 & 3 & 1.4 & 3.0 & 1.0 \\
\hline Z & 河内長野市 (湖畔) & 2004 年 4 月 -2004 年 12 月 & 3 & 0.8 & 1.0 & 0.6 \\
\hline
\end{tabular}

(a)

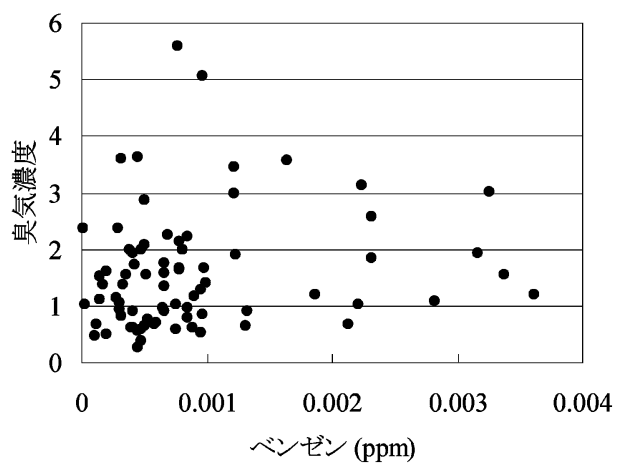

(c)

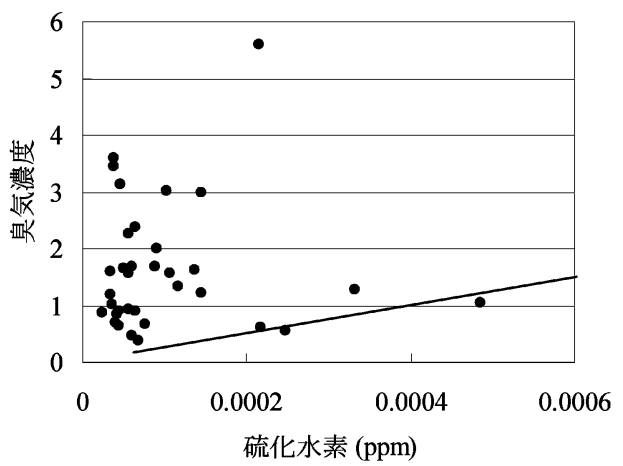

(b)

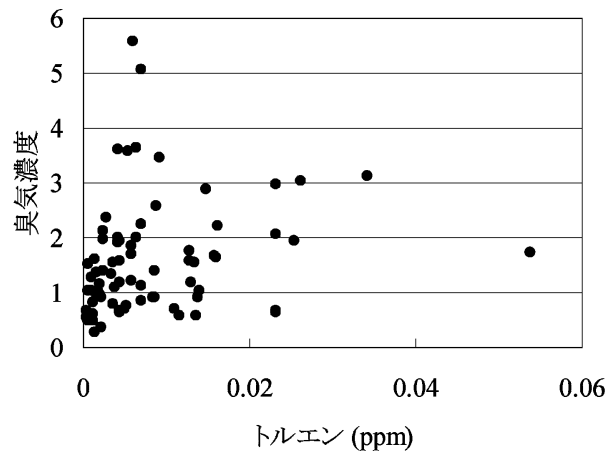

(d)

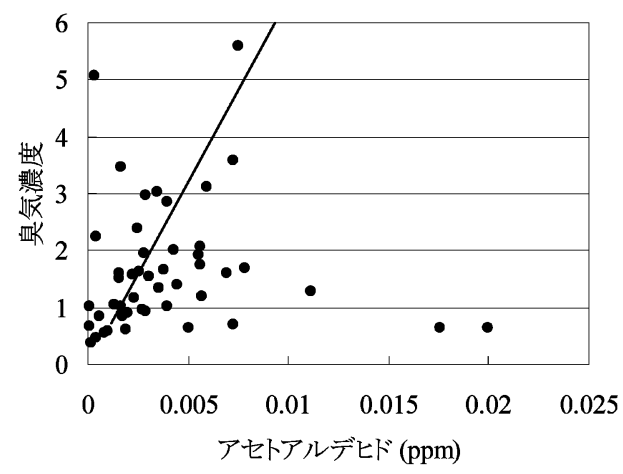

図－4 測定した臭気物質のうち代表的なもの（ベンゼン, トルェン, 硫化水素およびアセトアルデヒ ド）の測定結果と臭気濃度の関係

（c）および（d）の図中の直線は，その濃度に対する閾希釈倍数を示す。 
は閾値の $1 / 10$ 程度以下となっている。硫化水素の場合 は最も高濃度の場合は閾值レベルにまで達しているデー 夕があり，アセトアルデヒドの場合は閾值濃度よりも高 い測定值の割合が多かった。なお， A 地点でのみ測定し た低級脂肪酸類においても，酢酸（嗅覚閾值 0.0060 ppm）およびプロピオン酸（嗅覚閾值 $0.0057 \mathrm{ppm}$ ）濃度 は最大でもそれぞれ数 ppb またはその $1 / 10$ 以下のオー ダーであり閾値濃度未満であった。

測定した各物質について永田ら ${ }^{12)}$ の嗅覚閾值をもと に閾希釈倍数を求め, その最大值と臭気濃度の実測值, およびその合計值と臭気濃度の実測值との比較を図 -5 および図 -6 に示す。図 5 では，閾希釈倍数の最大值 が，実測值を上回っている場合が多く認められた。図一 4 のアセトアルデヒドの例と図ー5 を見比べて明らかな ように，図－5の結果は，ほぼアセトアルデヒドの閾希 釈倍数を反映しており, 実際 48 個のデータ中 43 個でア セトアルデヒドの閾希釈倍数が最大值となっている，臭 気濃度の測定結果は，沿道等での測定で高い結果が得ら れており，アセトアルデヒドの最大の発生源が自動車排 ガスであること ${ }^{13)}$ と一致する.

なお，アセトアルデヒド以外の物質の閾希釈倍数が最 大值となったものについては, 硫化水素 3 件 (J, I, T 地 点で各 1 回), メチルメルカプタン 1 件 (Z 地点で 1 回), エチルトルエン 1 件 (Z 地点で 1 回) のみであった. J 地 点については, 下水処理場付近のため硫黄系物質の影響 が大きくなったと考えられる。 その他の地点, 特に郊外 である $\mathrm{T}, \mathrm{Z}$ 地点は, アセトアルデヒド濃度が低いため に，他の物質の影響が相対的に大きくなったと考えられ るが，実際の発生源については不明である。なお，閾希 釈倍数の最大值の方が，実測值よりも大きくなる例が多 くみられる要因として, (1) 複数の臭気物質の共存による 感覚的相殺現象，(2)物質濃度の測定誤差，3臭気濃度測 定の䛊差，(4)解析に用いた嗅覚閾值の問題，などが考え られる。これらの要因について以下に示すように考察し たが特定には至れなかった。

(1)については，今回の事象ではアセトアルデヒド単独 の閾希釈倍数でも実測臭気濃度より大きいため可能性は 低い.

(2)について，一般に，都市域での大気中のアセトアル デヒド濃度は概ね $0.3 \sim 9 \mu \mathrm{g} / \mathrm{m}^{3} \quad(0.2 \sim 5 \mathrm{ppb})$ 程度であ る ${ }^{14)}$ が，ほとんどの結果はその範囲にあり，一部 $10 \mathrm{ppb}$ 以上の測定值もある。ここで，一般的な大気中アセトア ルデヒド分析結果は 1 日平均值であるため, 日中の 5 分 程度の測定值が高濃度であることは十分にあり得る。

(3) 臭気濃度測定の誤差には, 濃縮操作の誤差, すなわ ち回收率が低い，ということと嗅覚測定自体の誤差があ る。低温濃縮法では，特に低沸点成分の回収率が良好で

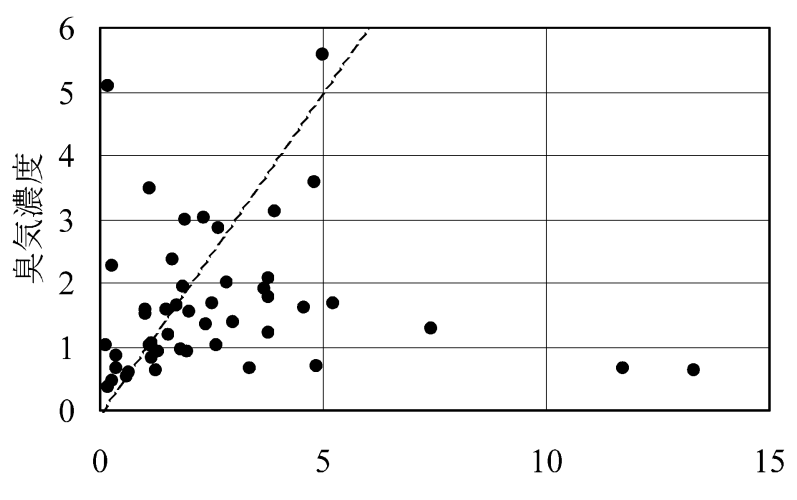

閾希釈倍数の最大值

図-5 臭気物質の閾希觅倍数の最大值と臭気濃度実測 値との関係

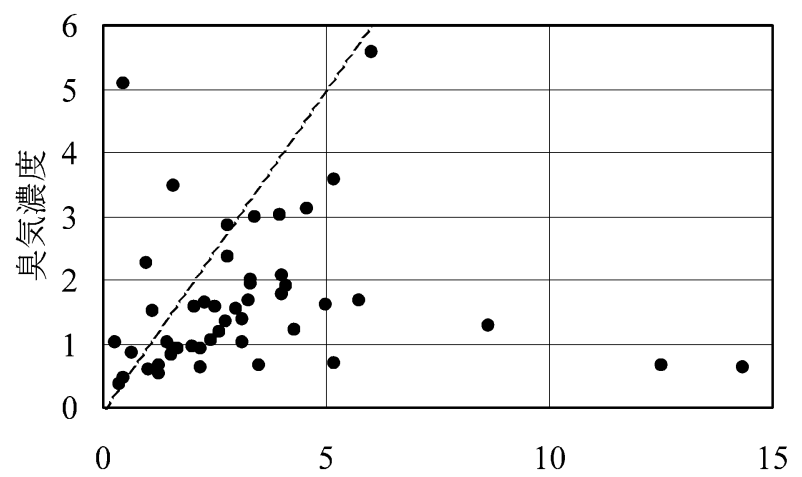

各臭気物質の閾希勫倍数の合計值

図-6 各臭気物質の閾希䣋倍数の合計値と臭気濃度実 測値との関係

あるために十分な回収率が得られていると考えられ，実 際にアセトアルデヒドの回収率を測定したところ $90 \%$ 以上で問題はなかった，後者については，被験者の検知 能力の個人差（被験者群としては室間変動）に依存する ところが大きい.

これに関連して (4)のアセトアルデヒドの閾值が問題 となる。アセトアルデヒドに対する閾希釈倍数の算出に は閾值濃度として $0.0015 \mathrm{ppm}$ を用いたが, 被験者群の アセトアルデヒドに対する閾值濃度が文献值と異なって いる場合も考えられる. アセトアルデヒドの嗅覚閾值 は, Amoore ${ }^{15)}$ が，いくつかの報告の幾何平均として $0.050 \mathrm{ppm}$ を算出しており, また Ruth ${ }^{16)}$ は, 文献值の幅 として $0.0002 \sim 4.14 \mathrm{mg} / \mathrm{m}^{3}(0.0001 \sim 2.2 \mathrm{ppm})$ としてい るなど，報告によって大きく異なっている，本来であれ ば，今回の調査実施時において，環境臭気測定を行うと 同時に被験者のアセトアルデヒドに対する嗅覚閾值濃度 を確認しておくべきであったが実施できていない，ただ し，各報告は測定方法が同一でなく，そういう点では今 回採用した $0.0015 \mathrm{ppm}$ は三点比較式臭袋法で測定され 
ているので最も適当であるはずである.

測定した物質の閾希釈倍数の合計值は最大值よりも当 然大きくなる. 図一6に示すように，図－5 と比べると各 プロットはやや右方向にシフトするがほぼ同様な図であ り，これはアセトアルデヒドの閾希釈倍数が他の物質に 比べて突出して大きいことを示している. なお, 閾希釈 倍数の合計值と閾希釈倍数の最大值との差は平均で 0.6 であった。

\section{4. まとめ}

本研究では，大阪市とその周辺において採取した試料 を低温濃縮して臭気濃度を測定し，あわせて物質濃度の 測定も行った. 結果の概要は以下の通りである.

臭気濃度の測定結果は， 0.3 から 5.6 であり，また，地 点ごとに平均した場合では 0.6 から 3.8 であった。地点 別の臭気濃度は，沿道では高く 1 を超え, 一方, 郊外や 川沿いでは低く 1 以下である傾向にあった。

環境臭気濃度に最も寄与している成分としてアセトア ルデヒドが考えられた。

\section{謝辞}

本研究は，臭気環境目標の設定に必要な臭気に係る量 反応関係に関する研究（環境省地球環境保全等試験研究 費, 平成 $14 \sim 17$ 年度）により行われたものの一部であ る. 研究代表者としてご尽力頂きました（独）産業技術総 合研究所 (現千葉大学工学部) 外池光雄先生に感謝致し ます。

キーワード : 環境臭気, 臭気濃度, 低温濃縮, 嗅覚測定 法，アセトアルデヒド

\section{参考文献}

1 ）辰市祐久，岩崎好陽，上野広行 ; 一般環境臭気の臭気濃 度测定法の検討。東京都環境科学研究所年報 1992，9-14 (1992)

2 ) 辰市祐久, 岩崎好陽, 上野広行, 早福正孝; 一般環境臭気 の臭気濃度測定法の検討 (2)一般環境臭気の測定結果につ
いて，東京都環境科学研究所年報 1993，177-180（1993）

3 ) 辰市祐久, 上野広行, 大岩川由有子; 道路からの臭気の 影響調查, 東京都環境科学研究所年報 1995, 192-198 (1995)

4 ）大岩川由有子，上野広行，辰市祐久; 工場周辺臭気の実 態調査一二オイ環境指針の策定に関する研究一，東京都環 境科学研究所年報 1996，128-133（1996）

5 ）辰市祐久, 上野広行; 東京都内の臭気環境について, 東 京都環境科学研究所年報 1997，207-215（1997）

6 ) 吉井直美; 千葉県における悪臭調査事例 一般環境臭気 の測定と原油流出事故調査結果，臭気の研究 28 (5), 301 -307 (1997)

7 ）増田淳二，福山丈二 ; 大阪市における環境大気の低濃度 臭気嗅覚測定，全国環境研会誌，27（4)，249-253（2002）

8 ) 遠藤孝二, 榎本長蔵, 岡本健一, 小坂芳雄, 村井政志 ; 嗅 覚測定用低濃度臭気捕集管の実用性，におい・かおり環境 学会誌，36（1），31-36（2005）

9 ）増田淳二，福山丈二 ; 常温濃縮による低濃度臭気嗅覚測 定の評価之大阪市における測定結果，大阪市立環境科学研 究所報告， 64，42-48（2002）

10) J. Masuda, J. Fukuyama, M. Tonoike and M. Yamaguchi; Cryogenic trapping for determination of odor concentration, Water Science \& Technology, 50 (4), 121124, 2004

11) U.S.EPA ; Compendium of methods for the determination of toxic organic compounds in ambient air. Second.Ed. (TO-14A), EPA/625/R-96/010b (1999)

12）永田好男, 竹内教文; 三点比較式臭袋法による臭気物質 の閾值測定結果，日本環境衛生セン夕一所報， 17, p77-89 (1990)

13）環境省環境保健部環境安全課; 化学物質ファクトシート 2004 年度版, p25（2005）

14）環境省環境保健部環境リスク評価室；化学物質の環境リ スク評価 第 1 巻, p44, (2002)（http : //www.env.go. jp/chemi/report/h14-05/chap01/03/02.pdf)

15) J.E. Amoore, E. Hautala ; Odors as an aid to chemical safety : odor thresholds compared with threshold limit values and volatiles for 214 industrial chemicals in air and water dilution, J. of applied toxicology, 3 (6), 272-290 (1983)

16) J.H. Ruth; Odor thresholds and irritation levels of several chemical substances: A review, Am. Ind. Hyg. Assoc. J., 47, A142-A151 (1986) 


\title{
Odor concentration of ambient air and odor substances in Osaka City and its suburbs
}

\author{
Junji MASUDA, Yasuyuki ITANO, Joji FUKUYAMA \\ Osaka City Institute of Public Health and Environmental Sciences, \\ 8-34, Tojo-cho, Tennoji-ku, Osaka 543-0026, Japan
}

\begin{abstract}
Urban air has potential for odor even when not clearly perceptible to humans. In the present study, low-level ambient odor concentrations in and around Osaka City, Japan, were determined by olfactometry after cryogenic condensation. The odor substances were also determined instrumentally and the relationship with odor concentration was examined.

The range of 92 odor concentrations observed at 26 points was 0.3 to 5.6 with the geometric average for each point ranging from 0.6 to 3.8. Odor concentration tended to be higher at roadside points and lower at suburban and riverside points. Acetaldehyde was considered to be the most significant odor substance in the urban atmosphere.
\end{abstract}

